\title{
PRELIMINARY RESEARCH: IDENTIFICATION OF MICROORGANISM IN THE WAITING ROOM ON PUBLIC TRANSPORTATION FACILITIES, DKI JAKARTA
}

\author{
Syarifah Miftahul El Jannah ${ }^{1}$, Cahyawati Rahayuㅁ, Zuraida ${ }^{2}$, Rian Prasetio ${ }^{1}$, \\ Rizki Iman Sugiarto ${ }^{2}$
}

\author{
${ }^{1}$ Jurusan Kesehatan Lingkungan Politeknik Kesehatan Kementerian Kesehatan Jakarta II, \\ ${ }^{2}$ Program Diploma III Analis Kesehatan Universitas MH. Thamrin, \\ E-mail : ajan4567@yahoo.com
}

\begin{abstract}
Public transportation is one of the places that have the potential to become a place of disease transmission, the discovery of bacteria in the facility is a public health problem is quite urgent. A preliminary test was conducted to find out the bacteria in waiting room at public transportation facilities in DKI Jakarta area. The research was conducted in cross sectional. Population are public facilities at the bus terminal of Kampung Rambutan, Pinang ranti, Manggarai, Grogol, Kalideres and Tanjung priuk. The sample is wipe the surface of iron fence, bench, handrail and counters as many as 24 samples. Conducted isolation on specific media and morphological, physiological and biochemical identification. We found 70 isolates with 5 species of bacteria, Staphylococcus aureus and Staphylococcus saphrophyticus 27.4\%, Bacillus subtilis 25.7\%, Staphylococcus epidermidis $17.14 \%$ and MRSA (Methicillin Resisten Staphylococcus Aureus) 2.8\%. Locations with the most bacteria types are iron grip and chair. Tanjung priuk is place the most bacteria type and found MRSA. Method and frequency of cleaning of transportation means become one factor to eliminate number and type of microorganism. Until now there are no regulations that bind to the hygiene and sanitation of transportation in particular.
\end{abstract}

Keyword: Public transportation facilities, Identification of microorganism

\section{UJI PENDAHULUAN : IDENTIFIKASI MIKROORGANISME PADA RUANG TUNGGU SARANA TRANSPORTASI UMUM DI WILAYAH DKI JAKARTA}

\begin{abstract}
ABSTRAK
Transportasi umum salah satu tempat-tempat yang berpotensi menjadi tempat penularan penyakit, ditemukannya bakteri pada sarana tersebut merupakan problem kesehatan masyarakat yang cukup mendesak. Telah dilakukan uji pendahuluan untuk mengetahui bakteri yang ada di terminal bis di Wilayah DKI Jakarta, penelitian dilakukan secara cross sectional dengan populasi adalah sarana umum di terminal bis Kampung rambutan, Pinang ranti, Manggarai, Grogol, Kalideres dan Tanjung priuk. Sampel adal;ah usap permukaan pagar besi, bangku, pegangan tangga dan loket sebanyak 24 buah. Dilakukam isolasi pada media spesifik dan identifikasi secara morfologi, fisiologi dan biokimia. Ditemukan 70 isolat dengan 5 spesies bakteri, Staphylococcus aureus dan Staphylococcus saphrophyticus masing-masing 27,4\%, Bacillus subtilis 25,7\%, Staphylococcus epidermidis 17,14\% dan MRSA (Methycilin Resisten Staphylococcus Aureus) 2,8\%. Lokasi dengan jenis bakteri terbanyak adalah pegangan besi dan kursi. Tanjung priuk merupakan terminal bis dengan jenis bakteri terbanyak dan ditemukan MRSA. Metoda dan frekuensi pembersihan sarana transportasi menjadi salah satu faktor untuk mengeliminasi jumlah dan jenis mikroorganisme. Sampai saat ini belum ada peraturan yang mengikat sekaitan dengan hygiene dan sanitasi transportasi secara khusus.
\end{abstract}

Kata Kunci :Sarana transportasi umum, identifikasi mikroorgasnime 


\section{PENDAHULUAN}

Alat transportasi saat ini sudah menjadi kebutuhan primer bagi manusia untuk mendukung kehidupannya, penggunaan alat transportasi umum atau massal menjadi salah satu pilihan, karena biaya yang dianggap lebih murah. Pada sistem transportasi diperlukan tempat sebagai terminal tujuan untuk menaikkan dan menurunkan penumpang. Terminal menjadi tempat berkumpul berbagai ragam manusia baik yang sehat, carier beberapa penyakit bahkan mungkin yang sedang sakit. Hal ini menyebabkan terminal dapat menjadi tempat penularan penyakit. Seperti yang diungkapkan oleh Mukono(1) tempat umum merupakan tempat bertemunya segala macam masyarakat dengan segala penyakit yang dimiliki oleh masyarakat.

Menurut travelmath.com telah dilakukan penelitian terhadap keberadaan mikroorganisme di dalam sistem transportasi di lima negara bagian di Amerika Serikat (New York City, Washington, D.C., Chicago, Boston, and San Francisco) dari usap pegangan pintu bis dan kereta api didapatkan rata-rata jumlah kuman 400.147 CFU/inchi ${ }^{2}$, dengan jenis bakteri yang ditemukan berturut-turut adalah Bakteri Gram positip coccus (Staphylococcus sp), jamur, bakteri Gram negatif batang (sebagian besar dari famili enterobacteriaceae) dan bakteri Gram positip batang (Bacillus sp) (2). Pada penelitian Paul Matewele dari 80 swab yang diambil dari pegangan tangga, tempat duduk, pintu dan dinding pada sarana transportasi bus di kota London mendapatkan 121 jenis isolat bakteri dari spesies Staphylococcus aureus, E.coli, Klebsiella pneumoniae dan Serratia sp (3). Dari penelitian tersebut maka sarana transportasi merupakan salah satu sumber penyebaran infeksi, sehingga perlu ada pengendalian dan pengawasan khusus.

Keputusan Menteri Perhubungan no. PM 132 tahun 2015 tentang Penyelenggaraan terminal penumpang angkutan jalan. Pada pasal 20 ayat 1 menjelaskan pada setiap penyelenggaraan terminal penumpang wajib menyediakan fasilitas terminal yang memenuhi persyaratan keselamatan dan keamanan (4). Hal ini tentu saja keamanan dari kemungkinan tertular/terinfeksi mikroorganisme yang berada pada sarana ditempat tersbut. Berdasarkan peraturan tersebut maka 
apakah terminal bis yang ada di wilayah DKI Jakarta saat ini dapat dikatakan aman dari berbagai sumber infeksi,? terutama infeksi bakteri yang dapat yang ditularkan melalui kulit dengan perantara sarana yang ada di dalam terminal. Seperti diketahui sebagian besar terminal di Jakarta masih jauh untuk dikatakan bersih apalagi hygiene. Berdasarkan hal tersebut sebagai uji pendahuluan peneliti ingin mengetahui mikroorganisme apa saja terutama bakteri yang dapat ditemukan pada sarana transportasi di wilayah DKI Jakarta. Untuk selanjutnya akan diteliti bagaimana teknik pengendalian yang tepat untuk meminimalisasi mikroorgasnisme tersebut. agar pengguna sarana transportasi tersebut merasa aman.

\section{METODA}

Penelitian bersifat potong lintang/cross sectional dengan populasi lima terminal diwilayah DKI Jakarta yaitu Terminal bis Pinang ranti, Terminal bis Kampung rambutan dalam dan luar kota, Terminal bis Manggarai, Terminal bis Kali deres, Terminal bis Grogol, dan Terminal bis Tanjung priuk. Sampel dalam penelitian ini adalah swab pegangan besi pagar, pegangan tangga, pegangan kursi, pegangan pada loket yang ada pada ruang tunggu terminal.

Sampel diambil dengan menggunakan lidi kapas steril dan medium transport Buffer pepton secara aseptik. Dilakukan pemeriksaan untuk mengisolasi bakteri yang terkandung, dengan menggunakan media blood agar (digunakan untuk mendapatkan mikroorganisme Gram positip dan Gram negatip), Mannitol Salt Agar (untuk mendapatkan Staphylococcus aureus) dan ORSIM media (digunakan untuk mendapatkan Staphylococcus yang telah resisten terhadap antibiotic methicilin). Untuk mengidentifikasi dilakukan pewarnaan Gram, uji katalase secara slide methode, uji koagulase dengan cara tabung dan uji Biokimia (uji fermentasi gula-gula, metabolisme Citrate, urea, ornithinase, motilitas, Indol) dengan penggunaan tabung fermentasi dan tabung biakan. Dikerjakan di Laboratorium Mikrobiologi Universitas MH. Thamrin.

\section{HASIL DAN PEMBAHASAN}

Setelah dilakukan pengambilan sampel dari 24 swab, didapat 70 isolat kuman, Staphylococcus aureus dan Staphylococcus saphrophyticus 
merupakan spesies bakteri yang paling banyak ditemukan (19 isolat/27,4\%) (Gambar 1). Staphylococcus aureus merupakan bakteri komensal dan patogen pada manusia. Sekitar 30\% dari populasi manusia dikolonisasi oleh Staphylococcus aureus, umumnya bakteri ini terdapat pada kulit, saluran pernapasan dan saluran pencernaan tanpa menyebabkan masalah kesehatan. Bakteri ini menjadi suatu masalah ketika terdapat suatu fokus infeksi dan dapat menyebar dari satu orang ke orang lain melalui kontak langsung atau melalui objek yang terkontaminasi. Staphylococcus aureus yang patogen bersifat invasif. Infeksi Staphylococcus aureus dapat menyebabkan bakterimia, endokarditis, osteoartikular, osteomielitis akut hematogen, infeksi pada kulit dan jaringan lunak, meningitis dan infeksi paru-paru ${ }^{5}$. Studi epidemiologi menunjukkan bahwa infeksi akibat Staphylococcus aureus di dunia meningkat pada dua dekade terakhir. Data di Amerika Serikat dan Eropa menunjukkan bahwa Staphylococcus aureus merupakan bakteri patogen tersering penyebab infeksi dengan prevalensi 18-30\%, sedangkan di wilayah Asia Staphylococus aureus dan Pseudomonas aeruginosa memiliki angka kejadian infeksi yang hampir sama banyak (6)

Staphylococcus epidermidis dan Staphylococcus saphtophyticus adalah

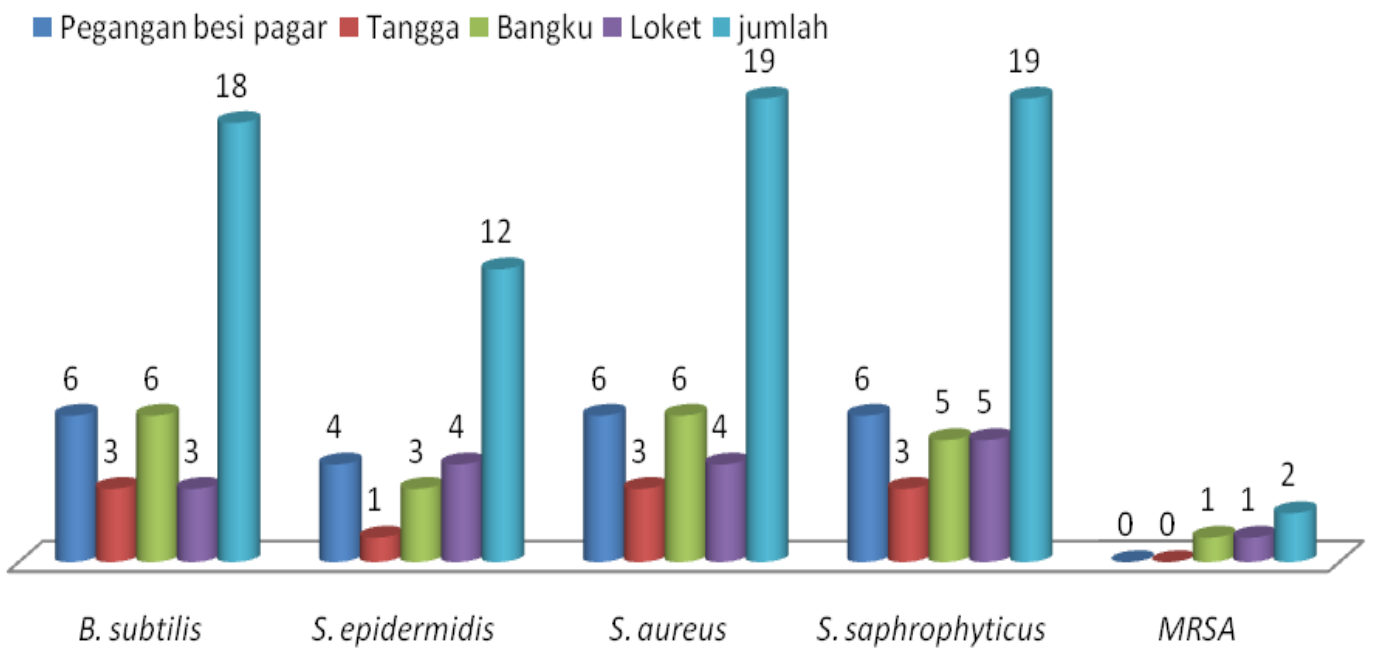

Gambar 1. Distribusi Isolat kuman pada beberapa sarana di terminal wilayah DKI 
mikroba flora normal pada kulit, bersifat nonpatogen, tidak invasif dan tidak hemolitik (7). Kedua spesies ini memang lazim ditemukan pada tempattempat umum. Sama halnya dengan bakteri Bacillus subtilis, bakteri berspora ini dapat bertahan lama di tanah/debu dan udara karena spora yang dimilikinya. Walaupun demikian bakteri-bakteri tersebut dapat menimbulkan penyakit bila masuk kedalam tubuh orang dalam kondisi imunitas yang rendah.

Dari uji pendahuluan ini juga ditemukan bakteri Staphylococcus aureus yang telah resisten terhadap antibiotik methicillin dikenal juga dengan nama MRSA atau Methicillin Resisten Staphylococcus Aureus, ditemukan pada swab berasal dari kursi dan loket. Seperti diketahui MethicillinResistant Staphylococcus aureus (MRSA) merupakan salah satu agen penyebab infeksi nosokomial yang utama. Bakteri MRSA berada di peringkat keempat sebagai agen penyebab infeksi nosokomial. Tetapi sejalan dengan pergerakan manusia maka saat ini MRSA juga banyak ditemukan pada beberapa tempat umum. Hal yang sama juga yang ditemukan pada penelitian di Universitas Arizona yang mendapatkan MRSA pada kereta api Amtrak (8). Lutz, et all (9) mendapatkan 3\% (25/40) kursi di dalam bus di Amerika Serikat terkontaminasi MRSA. Mendes (10) mendapatkan MRSA dengan prevalensi $16.1 \%$ pada bangku bus yang digunakan oleh mahasiswa Biomedika, serta menemukan $37,1 \%$ mahasiswa tersebut karier Staphylococcus aureus.

MRSA merupakan bakteri yang telah resisten terhadap obat antibiotik golongan $\beta$-laktam seperti Methicilin. Peningkatan resisten dapat disebabkan oleh pajanan terhadap antibiotik, selection pressure, penggunaan antibiotik yang tidak adekuat serta kolonisasi bakteri yang menyebabkan terjadinya Resistant endogen dari bakteri (11-13) Penelitian Conceica, et all (14) pada bus umum di dua kota besar di Portugal mendapatkan kontaminasi MRSA dengan tipe klon yang dominan di rumah sakit, hal ini membuktikan adanya perpindahan bakteri di rumah sakit yang menyebar ke masyarakat. Jika pada sarana transportasi ditemukan bakteri MRSA, maka penyebaran bakteri ini bisa menjadi lebih luas. 


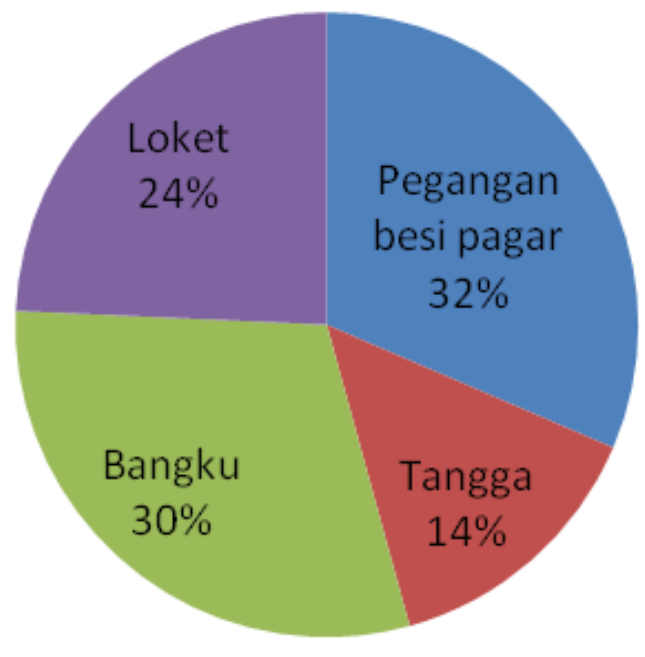

Gambar 2 Persentase Lokasi ditemukan bakteri di Terminal DKI Jakarta

Jika dilihat dari tempat ditemukannya bakteri terlihat bahwa permukaan bangku dan pegangan pagar merupakan tempat yang paling banyak ditemukan bakteri (Gambar 2), karena sarana ini paling sering disentuh oleh tangan ataupun kulit pengguna jasa transportasi. Maka seharusnya lokasi ini menjadi perhatian dalam pemeliharaan kebersihannya.

Terminal bis Tanjung Priuk merupakan terminal dengan jenis bakteri terbanyak ditemukan, pada terminal ini ditemukan lima spesies bakteri, selain itu bakteri MRSA ditemukan pada terminal ini (Gambar 3). Hal ini kemungkinan terjadi karena jumlah pengguna yang tinggi pada terminal ini, selain itu terminal bis Tanjung priuk tidak memiliki gedung tertutup sehingga pengotoran udara pada tempat tersebut sangat tinggi, serta frekuensi pembersihan yang sangat kecil. Terminal brikutnya yang juga banyak ditemukan bakteri adalah terminal bis Grogol dan Kampung rambutan, kedua terminal bis ini merupakan pintu masuk ke wilayah DKI Jakarta dengan jumlah pengguna yang juga padat.

Kebersihan mampu meninimalisasi keberadaan mikroorganisme disuatu tempat. Maka pada terminal bis, metoda dan frekuensi pembersihan menjadi sangat penting. Penggunaan desinfektan ataupun lap yang mengandung antibakteri dapat digunakan untuk membunuh kuman yang ada pada suatu tempat. Selain tentunya memcuci tangan dengan sabun dan air mengalir menjadi rekomendasi utama bagi setiap orang, terutama bila setelah

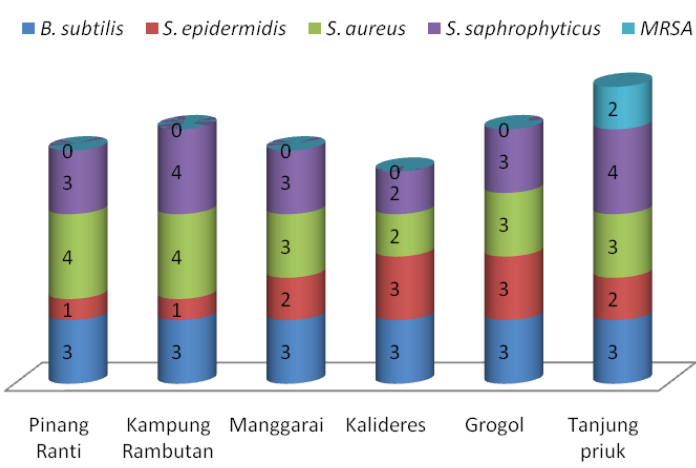

Gambar 3 Jenis mikroorganisme yang ditemukan berdasarkan lokasi sampling

Syarifah Miftahul El Jannah, et al | 132 
menggunakan transportasi umum.

Sarana transportasi merupakan media lingkungan yang berhubungan dan berdampak langsung terhadap kesehatan masyarakat, seperti tertera pada PP RI no. 66 tahun 2014 tentang Kesehatan Lingkungan pasal 8 menyatakan tempat dan fasilitas umum merupakan media lingkungan yang harus ditetapkan standart baku mutu lingkungannya (15). Sampai saat ini Kementerian Kesehatan belum mengeluarkan peraturan yang berkaitan dengan higiene dan sanitasi transportasi, sehingga bentuk pengendalian dan pengawasan agak sulit ditegakkan.

Sampai saat ini penelitian sedang dilanjutkan untuk mengamati variable pengendalian dan pengawasan serta menginventarisasi bakteri Gram negatif dan jamur.

\section{SIMPULAN DAN SARAN}

Dari penelitian awal ini ditemukan 70 isolat kuman yang diambil dari beberapa sarana di terminal bis di wilayah Jakarta, didapat 5 spesis bakteri, Staphylococcus aureus dan Staphylococcus saphrophyticus masingmasing 27,4\%, Bacillus subtilis 25,7\%, Staphylococcus epidermidis 17,14\% dan MRSA 2,8\%. Sedangkan fasilitas dengan jenis bakteri terbanyak adalah pegangan besi pagar (32\%) dan bangku (30\%) dan terminal bis dengan jenis spesies terbanyak adalah Tanjung Priuk.

Perlu dilakukan penelitian lebih lanjut untuk mengendalikan kontaminasi mikroorganisme pada sarana transportasi umum tersebut untuk selanjutnya digunakan sebagai dasar dalam penyusunan baku mutu higiene sanitasi bagi sistem transportasi umum.

\section{DAFTAR PUSTAKA}

1. Mukono, HJ. Prinsip Dasar Kesehatan Lingkungan. Airlangga University Press. Surabaya, 2006.

2. Public Transportation, Hygiene exposed, [cited 2017 August 11]. Availabe from : https://www.travelmath.com/featur e/public-transportation-hygieneexposed/

3. Matewell P. London's filthiest tube lines revealed: which bacteria are you sharing a carriage with?. London Underground, [cited 2017 August 11]]. Available from: http://www.wired.co.uk/topic/lond on-underground.

4. Peraturan Menteri Perhubungan Republik Indonesia Nomor PM 132 tahun 2015, Tntang Penyelenggaraan Terminal Penumpang Angkutan Jalan.

5. Jawetz, Melnick, \& Adelberg, Mikrobiologi Kedokteran Ed.23, Alih bahasa oleh Hartanto, H., Jakarta: EGC,2008.

6. Tong et al., Species Staphylococcus argenteus: The taxonomy from the rank of class and below is based 
upon currently published taxonomic opinion. 2015

7. Brooks GF, Butel JS, Morse SA. Mikrobiologi kedokteran.Alih Bahasa. Mudihardi E, Kuntaman,WasitoEB et al. Jakarta: Salemba Medika. 2005

8. Gabby K, The hidden dangers of public transportation, The Brandeis Hott, University's Community Newspaper Waltham, Mass. Published: October 29, 2010 (cited 2017 Juli 19). Available from: http://www. thebrandeishoot.com/articles/8865.

9. Lutz JK, Van Balen J, Crowford JM, Wilkins JR et all, Methicillinresistant Staphylococcus aureusin public transportation vehicles (buses): Another piece to the epidemiologic puzzle, American Journal of Infection Control, 2014,Vol. 42, December,p.12851290.

10. Mendes A. Martins da Costa, Rego, D, Beça N, Alves C, Moreira T, Conceição $\mathrm{T}$, Aires-de-Sousa $\mathrm{M}$, Contamination of public transports by Staphylococcus aureus and its carriage by biomedical students: point-prevalence, related risk factors and molecular characterization of methicillinresistant strains, Public Health, 2015, Volume 129, Issue 8, August, Pages 1125-1131.

11. Harbarth SJ, Pittlet D., The intensive care unit: part a. HAI epidemiology, risk factors, surveillance, engineering and administrative infection control practices, and impact. In: Jarvir WR (editor). Bennet and brachman's hospital infection, 5th ed. Philadelphia: Lippincot Williams and Wilkins. 2007.
12. Fraser VJ, Kollef MH., Antibiotic Resistance in the Intensive Care Unit, Annals of Internal Medicine. 2001, 02/20/2001, Vol. 134 Issue 4, p298..

13. Kollef $\mathrm{MH}$, Time To Get Serious about Infection Prevention in the ICU , CHEST, 2006, Nov, Vo. 130, Issue 5, p.1293

14. Conceic T. Fernanda Diamantino, Céline Coelho, Hermínia de Lencastre and Marta AiresdeSousa, 2013, Contamination of Public Buses with MRSA in Lisbon, Portugal: A Possible Transmission Route of Major MRSA Clones within the Community. Plos One, Volume 8, issue 11, e77812,

15. Peraturan Pemerintah Republik Indonesia Nomor 66 Tahun 2014, tentang Kesehatan Lingkungan, diperbanyak oleh Direktorat Penyehatan Lingkungan Kementerian Kesehatan RI, Tahun 2014 